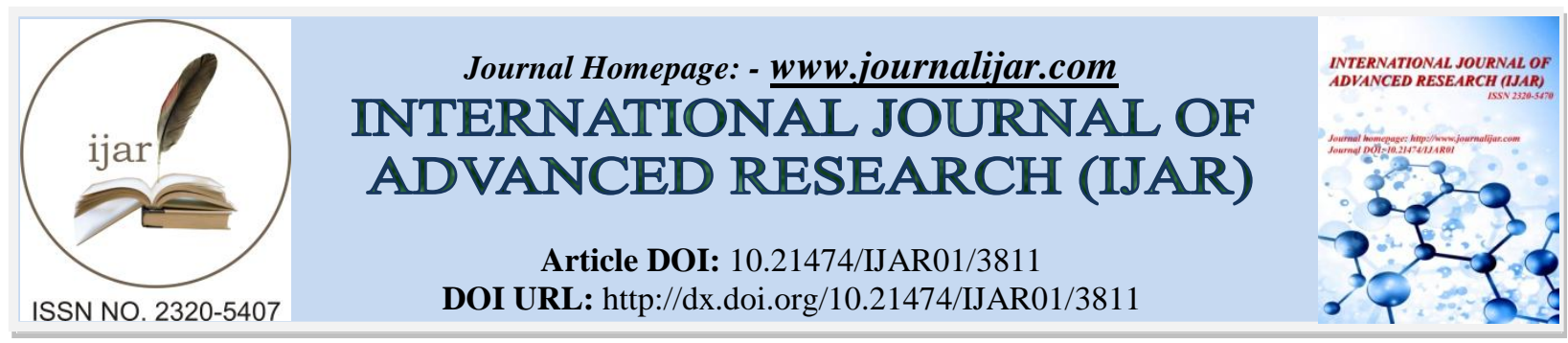

RESEARCH ARTICLE

\title{
OPTIMIZATION STUDIES ON ALKALINE PROTEASE FROM ASPERGILLUS TERREUS ISOLATED FROM MARINE SOIL.
}

Suman Kumar and "M. Raghu Ram.

Department of Botany \& Microbiology, Acharya Nagarjuna University, Guntur, A.P.

\section{Manuscript Info}

Manuscript History

Received: 01 February 2017

Final Accepted: 02 March 2017

Published: April 2017

\begin{abstract}
Extracellular proteases have high commercial value and multiple application in detergents, food, dairy, pharmaceutical, leather, diagnostics, waste management and several recovery industries. The Aspergillus terreus isolated from kottakoduru seashore, Nellore, was found to produce alkaline protease. Maximum enzyme production was recorded at $\mathrm{pH} 8$ and temperature of $30{ }^{\circ} \mathrm{C}$ in a medium containing $10 \%$ wheat bran. $\mathrm{ZnSO}_{4}$ is effective activator for protease activity and PMSF had given approximately $50 \%$ inhibition, indicating that it is a serine protease. Sesame oil cake proved to be suitable substrate after wheat bran for the production of protease by Aspergillus terreus.
\end{abstract}

Copy Right, IJAR, 2017,. All rights reserved.

\section{Introduction:-}

Microbial enzymes gained much attention due to their industrial application in clean, environmental-friendly and coast effective biotechnological processes. A protease (E.C No.3.4) breaks down proteins. A protease is an enzyme that conducts proteolysis, that is, begins protein catabolism by hydrolysis of the peptide bonds that link amino acids together in the polypeptide chain forming the protein. Extracellular proteases are involved in the hydrolysis of proteins in the outer cell environment and enable the cell to absorb and utilize hydrolytic products (Joo et al., 2005).

Extracellular proteases have high commercial value and multiple application in detergent, food, diary, pharmaceutical, leather, diagnostic, waste management and silver recovery. The microbial protease represents $60 \%$ of the worldwide market with sales of more than $\$ 350$ million annually (Kirk et al.,2002). Proteases are among the most important class of industrial enzymes, which constitute more than $65 \%$ of the total industrial applications, such as laundry detergent, i.e., help in removing protein based stains from clothing (Banerjee et al., 1999), leather preparation, meat tenderization, peptide synthesis, food industry, de-hairing process, pharmaceutical industry in contact lens eye cleaners and as an active component in enzymic debriders in view of its ability to digest various protein substrates, (Anwar and Saleemudin, 2000) as well as in bioremediation process (Gupta et al Roy, 2002 ; Oskouie et al., 2008).

Solid state fermentation (SSF) was chosen for the present study as it has been reported to be of more grated productivity than that of submerged fermentation (Ghildyal et al., 1985). Economically, SSF offers many advantages including superior volumetric productivity, use of simpler machinery, use of inexpensive substrates, simpler downstream processing, and lower energy requirements when compared with submerged fermentation (Paranthaman et al., 2009). Fungi elaborate a wide variety of proteolytic enzymes than bacteria. The filamentous fungi have a potential to grow under varying environmental conditions such as $\mathrm{pH}$ and temperature and utilizing a wide variety of substrates as nutrients (Haq et al., 2004). Several fungal species (Aspergillus flavus, A. melleu, A. niger, 
Chrysosporium keratinophilum, Fusarium graminarum, Penicillium griseofulvin, Scedosporium apiosermum) and bacteria (Bacillus licheniformis, Bacillus firmus, B. alcalophilus, B. amyloliquefaciens, B. proteolyticus, B. subtilis, B. thuringiensis) are reported to produce proteases (Ellaiah et al., 2002).

Alkaline proteases find diagnostic and therapeutic applications. Among the total microbial proteases the most commercially important are the alkaline proteases, especially those from fungal source. The use of immobilized alkaline protease from microbial source having therapeutic properties was studied for the development of soft gelbased therapeutic formulas, gauze, non-woven tissues and bandage materials. Proteases from Aspergillus oryzae were orally used as a therapeutic and diagnostic aid to treat certain lytic enzyme deficiency syndromes. Despite the extensive research done on protease, the need of a novel protease with wide applications in industrial application is increasing day by day. In the present study the optimization of protease production by Aspergillus terreus was carried out.

\section{Materials and Methods:-}

Soil samples were collected from 3 different sites of kothakoduru seashore area, Nellore dist, AP. The samples were collected randomly from one feet depth in seashore area. Serial dilutions were prepared using the representative composite soil samples collected from the sites, spread on the PDA plates and incubated for 72 hours at room temperature. The isolated colonies obtained were sub cultured on the slants and these pure cultures were used in this study.

\section{Qualitative Screening of Alkaline Protease:-}

Skim milk agar medium was used for qualitative screening for alkaline protease production (Sharma et al., 2006). The medium comprises of skim milk powder $100 \mathrm{gm}$, peptone $5 \mathrm{~g}$ and agar $20 \mathrm{~g}$ per litre with $\mathrm{pH}$ 8.0. The isolated fungi from the pure slants were inoculated on to the skim milk agar plates and incubated at room temperature for 72 hours. After incubation the fungi which produce clear zone around the colony were selected and sub cultured and finally transferred to Potato dextrose agar slants and maintained at $4{ }^{\circ} \mathrm{C}$. The positive fungal strain which produced maximum zone of clearance was morphologically identified as Aspergillus terreus and used in this study.

\section{Preparation of Enzyme Extract:-}

Conical flasks $(250 \mathrm{ml}$ ) containing $10 \mathrm{~g}$ of wheat bran (substrate) with $15 \mathrm{ml}$ of moistening agent were sterilized at $121^{\circ} \mathrm{C}\left(15 \mathrm{lbs} /\right.$ inch pressure), cooled and inoculated with the fungal stain and incubated at $30{ }^{\circ} \mathrm{C}$ for $72 \mathrm{hrs}$. After incubation, $80 \mathrm{ml}$ of distilled water was added to the flask, and was shake on a rotary shaker for $14 \mathrm{hrs}$ at $200 \mathrm{rpm}$. The content of flask was filtered and filtrate was analyzed for enzymatic activity.

\section{Protease Assay:-}

The Protease activity in the crude enzyme extract was assayed by using $1 \%$ casein in citrate buffer (pH 7). The reaction mixture contained $1 \mathrm{ml}$ casein and $1 \mathrm{ml}$ crude enzyme extract and was allowed to stand for $1 \mathrm{hr}$ at the room temperature. After $1 \mathrm{hr}, 5 \mathrm{ml}$ tri chloroacetic acid (TCA) was added to stop enzymatic reaction. After addition of the TCA, the tubes were shaken and then the contents were centrifuged at $10000 \mathrm{rpm}$ for $15 \mathrm{~min}$. To the supernatant $5 \mathrm{ml}$ of $\mathrm{Na} \mathrm{OH}$ solution was added allowed to stand for another $15 \mathrm{~min}$. Finally $0.5 \mathrm{ml}$ of Folin- ciocalteu reagent ( FC reagent) was added and intensity of blue color developed was measured at $700 \mathrm{~nm}$ within half an hour using Spectrophotometer. The amount of enzyme produced can be calculated by standard graph of tyrosine. One unit of enzyme activity is defined as the amount of the enzyme that releases $1 \mu \mathrm{g}$ of tyrosine $\mathrm{mL} \mathrm{G}^{-1}$ of crude enzyme per hour.

\section{Optimization studies:-}

Production of protease from Aspergillus terreus was optimized by controlling different physico chemical parameters like $\mathrm{pH}$, temperature, metal ions together with different substrates for the better yield of enzyme. These optimization studies were carried out at different times of incubation viz., 24, 48,72 and 96hrs.

\section{Standardization of substrate:-}

Four oil seed cakes, including sesame oil cake, ground nut oil cake, cotton seed oil cake along with wheat bran were used as substrates in this study. The moistening agent (mineral medium) was prepared with the composition of $0.5 \%$ ammonium nitrate $\left(\mathrm{NH}_{4} \mathrm{NO}_{3}\right), 0.2 \%$ Potassium di hydrogen phosphate $\left(\mathrm{KH}_{2} \mathrm{PO}_{4}\right), 0.2 \%$ Magnesium sulphate $\left(\mathrm{MgSO}_{4}\right)$ and $0.1 \%$ Sodium chloride $(\mathrm{Na} \mathrm{Cl})$ in water. 
Among the four substrates, for the best proved substrate, the effective concentration was identified by screening the enzyme production at different concentrations $(2.5$ to $12.5 \%)$ of the substrate.

\section{Optimization of temperature and $\mathrm{pH}:-$}

For temperature optimization, enzyme production at different temperatures ranging from 20 to $40^{\circ} \mathrm{C}$ was estimated. Similarly for $\mathrm{pH}$ optimization, enzyme production at different $\mathrm{pH}$ ranging from 6.5 to 8.5 was estimated at three incubation times.

\section{Effect of activators and inhibitors:-}

Various chemicals were tested at $0.1 \mathrm{M}$ concentration as activators and inhibitors while assaying the protease activity. The activators used were metal ions like zinc sulphate $\left(\mathrm{ZnSO}_{4}\right)$, Calcium chloride $\left(\mathrm{CaCl}_{2}\right)$ and Ferrous sulphate $\left(\mathrm{FeSO}_{4}\right)$ and the inhibitors included PMSF (phenyl methyl sulphonyl fluoride), SDS and EDTA.

\section{Results and discussion:-}

The use of natural and cheap substrate in the process of enzyme production has been investigated using various agro industrial products. Wheat bran has been reported to be a potent substrate among various agro by products used in different growth systems (SSF,SMF and Two phase system) by several workers (Kaur et al., 2001; Sumantha et al., 2005; Naidu and Devi, 2005). In the present study maximum protease production of $580 \mathrm{IU}$ was recorded after 72 hrs incubation when $10 \%$ of wheat bran was used as fermentation medium. With further increase in substrate concentration the enzyme production decreases. Similar type of results were reported by Kranthi et al.,(2012) with A. flavus and A. oryzae. However Osman et al., (2014) reported that $4 \%$ wheat bran is optimum for Aspergillus terreus and also reported that at 5\% concentration there is a decline in enzyme production. Muthulakshmi $e t$ al.,(2011) reported that $3 \%$ wheat bran was optimum for Aspergillus flavus.

Next to the wheat bran, sesame oil cake was found to be effective substrate for maximum protease production. Oil cakes have been widely used as substrates for the production of industrial enzymes using fermentation process since they provide both carbon and nitrogen sources in the nutrient medium (Ramchandra et al., 2007).

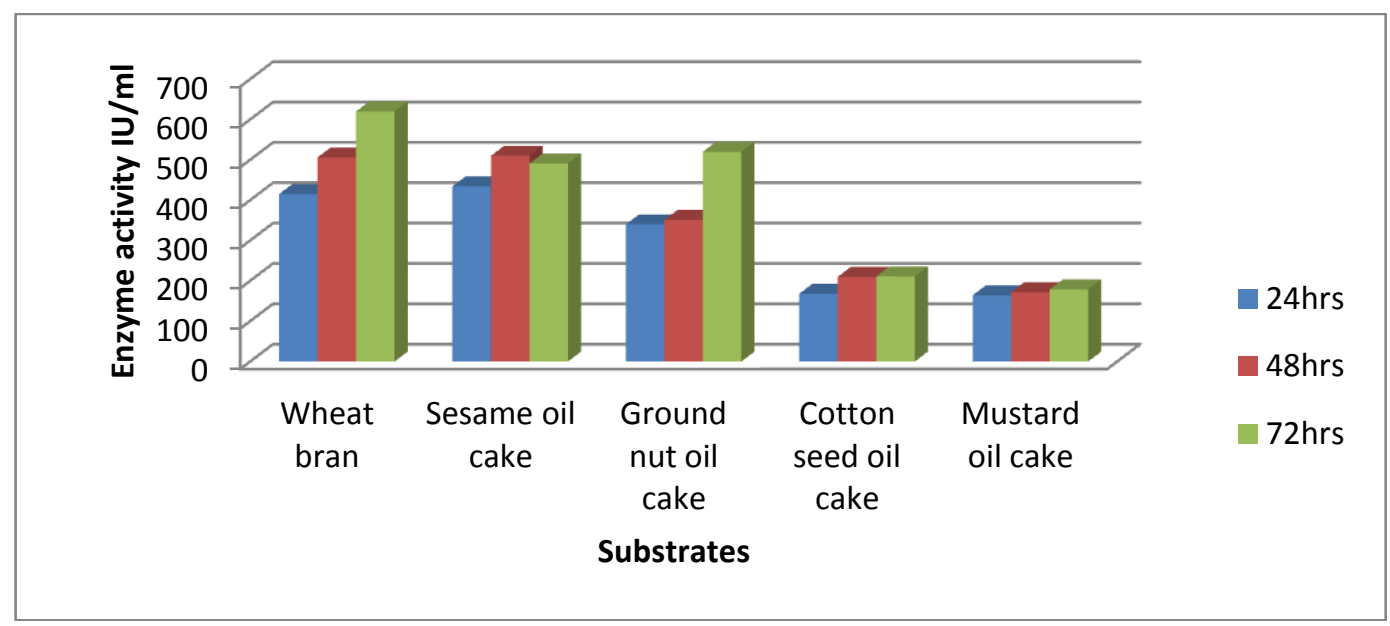

Fig 1:- Effect of different substrates on protease production by Aspergillus terreus 


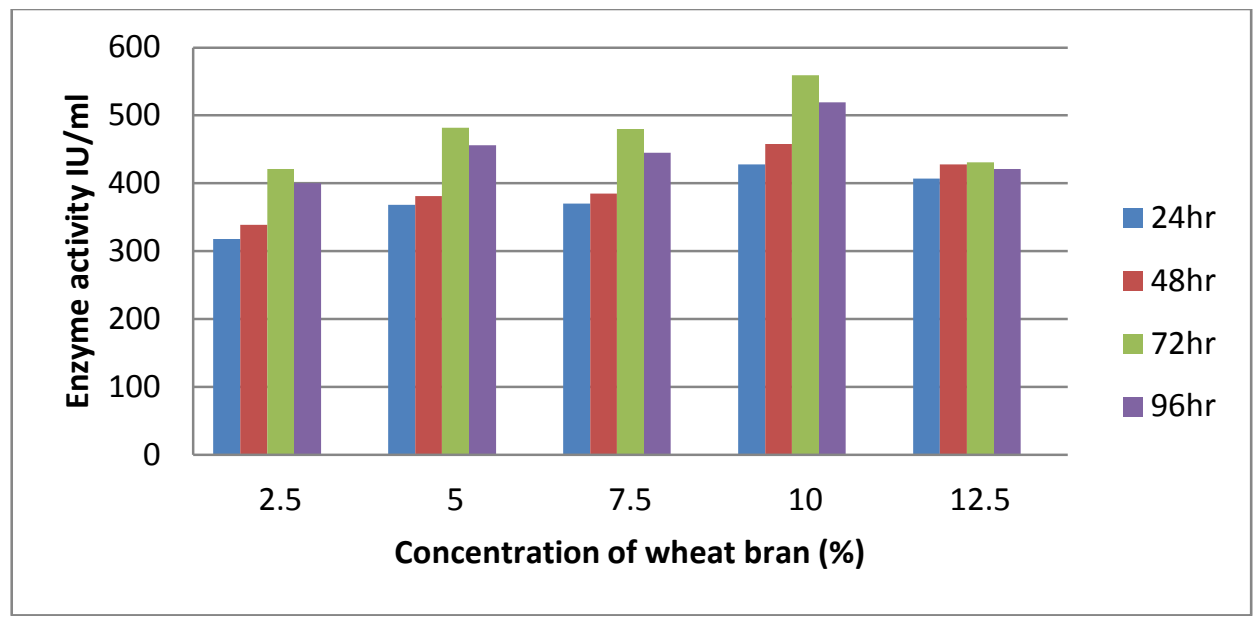

Fig. 2:- Effect of different concentrations of wheat bran on protease production by

Aspergillus terreus

Effect of pH and Temperature:-

The important physical factors that determine rate of bioprocessing are $\mathrm{pH}$ and temperature .The productivity of enzyme greatly depends on $\mathrm{pH}$ of the medium. Therefore the effect of $\mathrm{pH}$ from 6.5 to 8.5 was studied for protease production by Aspergillus terreus. There was gradual increase in protease production from $\mathrm{pH} 6.5$ to 8 and maximum production was observed at $\mathrm{pH} 8$ with $510 \mathrm{IU}$. Similar results were reported by Gopal Kumar et al.,(2016), Chellapandi (2010) and Hussain et al., (2010) in A. terreus. However acidic protease production by $A$. terreus was reported by Sethi et al.,(2015) and Chakrabarthi et al.,(2000) at $5.5 \mathrm{pH}$ indicating the strain variation within the species.

Alkaline proteases reported to have optimum activity in the $\mathrm{pH}$ range 8-9. It was reported that protease production from microbial source can be acidic or alkaline depending on the type of organism and source of the isolation. Pagare et al., (2009) reported an optimum pH of 8 for extracellular protease production from Aspergillus niger and Bacillus subtilis. According to Borris, (1987) alkaline protease production by microbes was found to be higher at $\mathrm{pH}$ range of 9-13. Osman et al.,(2014) reported that at $\mathrm{pH} 7$ the maximum enzyme activity by Aspergillus terreus isolated from soil. Muthulakshmi et al.,(2011) also reported that at $\mathrm{pH} 7$ the maximum enzyme activity by Aspergillus flavus .

In the present study the effect of temperature $\left(20-40^{\circ} \mathrm{C}\right)$ was studied for protease production by Aspergillus terreus. A gradual increase in enzyme production was observed with increase in temperature up to $30^{\circ} \mathrm{C}$ and reached the peak with production of $425 \mathrm{IU}$. Then it decreased and minimum production was recorded at $40^{\circ} \mathrm{C}(351 \mathrm{IU})$ which is almost similar to that observed at $20{ }^{\circ} \mathrm{C}$. As a secondary metabolite this enzyme was produced during exponential phase of the growth, the incubation at high temperature could lead to poor growth and thus a reduction in enzyme yield (Sabu et al., 2002). Chandrasekaran et al., (2015) showed similar type of results. Osman et al., (2014) reported that the purified enzyme from Aspergillus terreus was active at $55^{\circ} \mathrm{C}$ and stable till $45^{\circ} \mathrm{C}$ isolated from soil. Gopalkumar et al.,(2016) reported that the maximum protease activity at $60^{\circ} \mathrm{C}$ temperature for Aspergillus terreus $B A B$-346 isolated from paper mill area ,Banana farm and poultry farm area. Niyonzima et al.,(2014) reported that higher enzyme activity at $50^{\circ} \mathrm{C}$ by Aspergillus terreus. Chellapandi (2010) reported that there was optimum enzyme activity for Aspergillus flavus and Aspergillus terreus at temperature of 45 and $60^{\circ} \mathrm{C}$ respectively, isolated from soil around leather industry. Sethi et al.,(2015) reported that optimum temperature for production of protease was $30{ }^{\circ} \mathrm{C}$ by Aspergillus terreus isolated from isolated from chuckling vetch. This clearly indicates that variation in temperature requirement for enzyme production is strain dependent. 


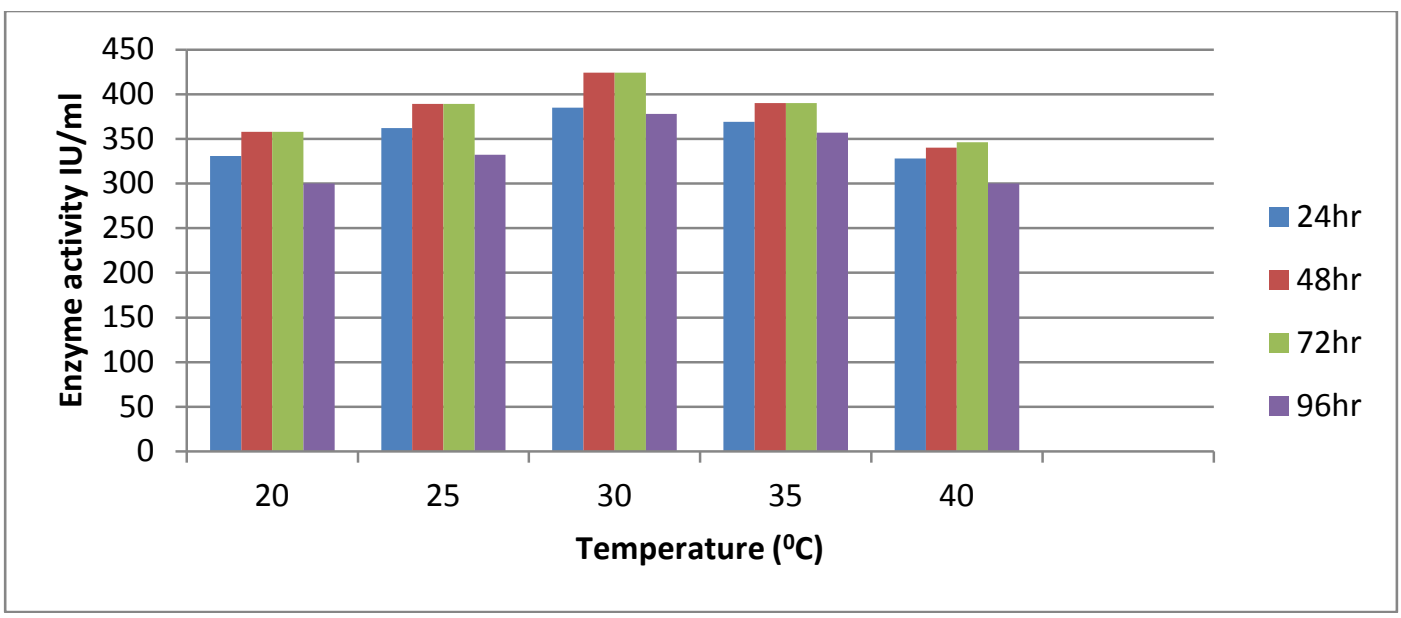

Fig.4:- Effect of temperature on protease production by Aspergillus terreus

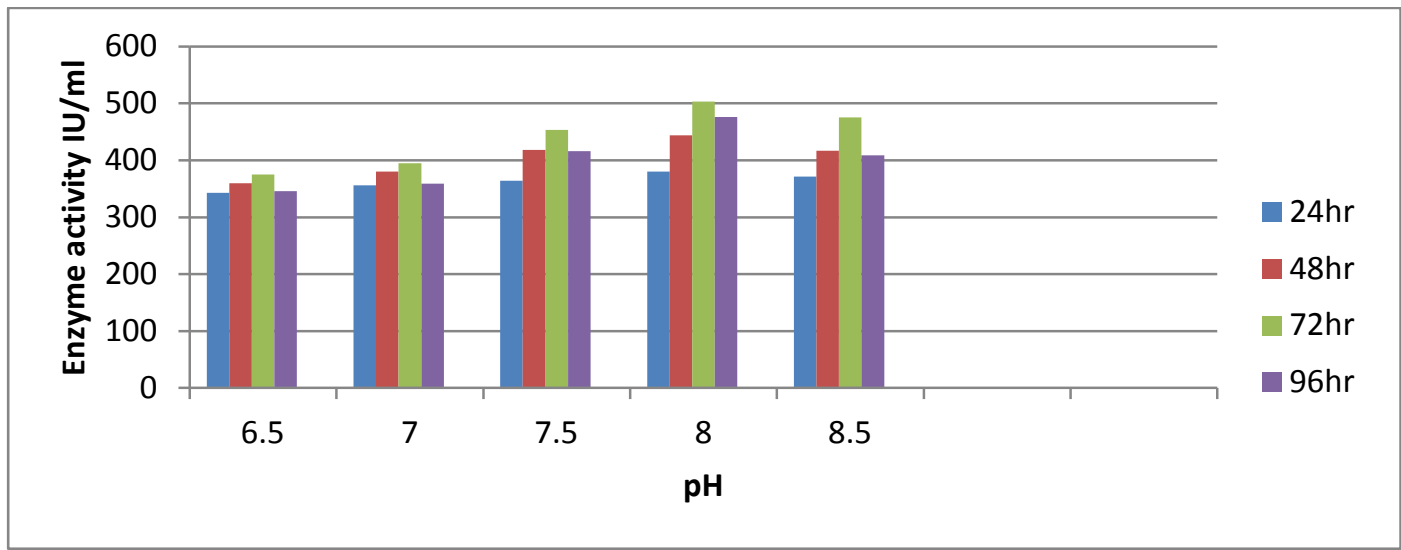

Fig.5:- Effect of pH on protease production by Aspergillus terreus

\section{Effect of inhibitors and Activators:-}

While studying the effect of activators it was observed that $\mathrm{ZnSO}_{4}$ enhanced the protease activity up to $510 \mathrm{IU}$ followed by $\mathrm{Fe} \mathrm{SO}_{4}(461 \mathrm{IU})$ and $\mathrm{Ca} \mathrm{Cl}_{2}(412 \mathrm{IU})$. Gopalkumar et al., (2016) reported that $\mathrm{Zn}^{2+}$ inhibited the enzyme activity up to $80 \%$, but $\mathrm{Cu}^{2+}$ enhanced the enzyme activity up to $122 \%$ in Aspergillus terreus $-B A B-346$. Sethi et al ., (2015) reported that $\mathrm{Fe}^{2+}$ affects the enhanced production of protease by Aspergillus terreus. Sumantha et al.,(2005) reported that protease was activated through $\mathrm{Ca}^{2+} \mathrm{Fe} 2+$ and $\mathrm{Mg}^{2+}$. In the present study, PMSF was found to be an effective inhibitor for the production, indicating that the protease produced by A.terreus was a serine protease. Similar results were reported by Srilakshmi et al., (2014) and Oman et al.,(2014) . After PMSF, EDTA and SDS also inhibited the enzyme production. Chellapandi (2010) reported that the enzyme activity of Aspergillus flavus completely inhibited by EDTA. This clearly indicated the presence of serine metallo type protease. 


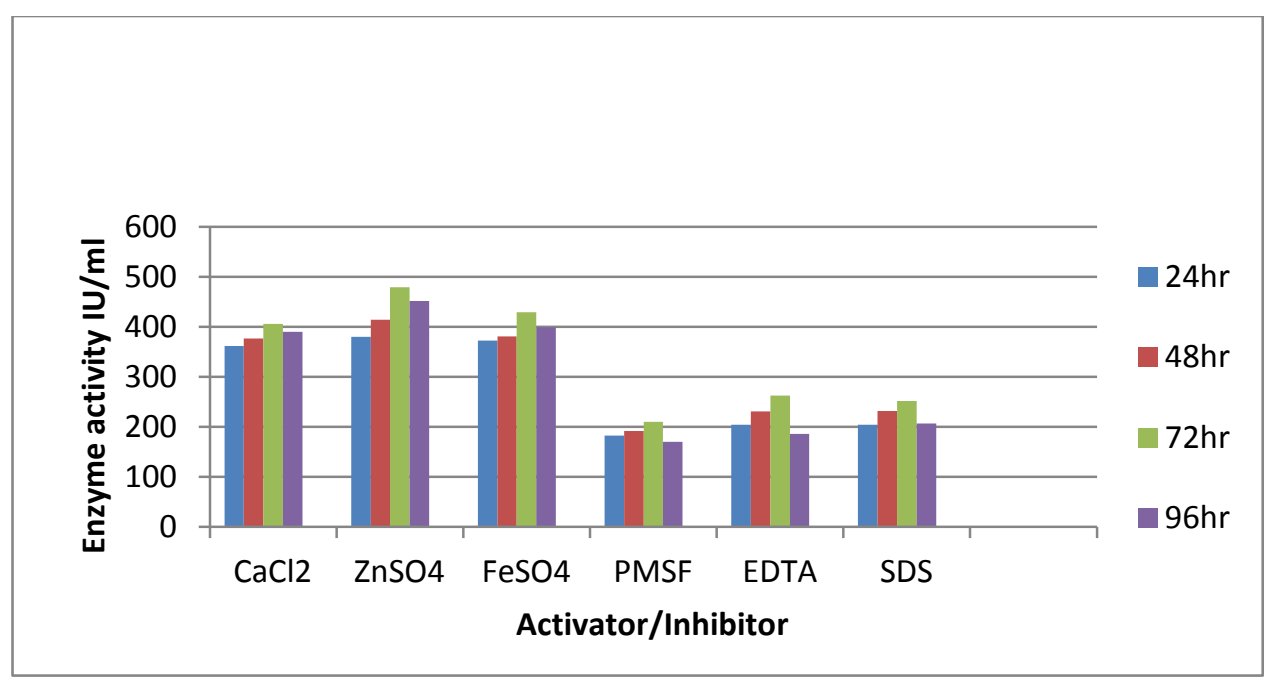

Fig-6:- Effect of Activator/ Inhibitor on protease production by Aspergillus terreus

\section{Conclusions:-}

Aspergillus terreus isolated from marine soil could produce serene metello type alkaline protease of 580 IU when $10 \%$ of wheat bran was used as substrate, at $\mathrm{pH} 8.5$ and $30^{\circ} \mathrm{C}$ temperature after $72 \mathrm{hrs}$ of incubation.

\section{Acknowledgements:-}

Authors are thankful to Head, Dept. of Botany \& Microbiology, Acharya Nagarjuna University for providing the facilities.

\section{References:-}

1. Anwar, A. and Saleemuddin, M., 2000. Alkaline protease from Spilosoma obliqua: potential applications in bio-formulations. Biotechnology and applied biochemistry, 31(2), pp.85-89.

2. Banerjee, U.C., Sani, R.K., Azmi, W. and Soni, R., 1999. Thermostable alkaline protease from Bacillus brevis and its characterization as a laundry detergent additive. Process biochemistry, 35(1), pp.213-219.

3. Borriss R. 1987. Biology of enzymes. In: (Rehm H \& Reed G. eds) Biotechnology. Weinheim, Verlag chemie. pp. 35-62.

4. Chakrabarti, S.K., Matsumura, N and Ranu R.S, 2000. Purification and characterization of an extracellular alkaline serine protease from A. terreus, Curr Microbiol, 40: 239-244.

5. Chandrasekaran, S., Kumaresan, S.S.P. and Manavalan, M., 2015. Production and Optimization of Protease by Filamentous Fungus Isolated from Paddy Soil in Thiruvarur District Tamilnadu. Journal of Applied Biology and Biotechnology Vol, 3(06), pp.066-069.

6. Chellapandi, P., 2010. Production and preliminary characterization of alkaline protease from Aspergillus flavus and Aspergillus terreus. Journal of Chemistry, 7(2), pp.479-482.

7. Dubey, R., Adhikary, S., Kumar, J. and Sinha, N., 2010. Isolation, production, purification, assay and characterization of alkaline protease enzyme from Aspergillus niger and its compatibility with commercial detergents. Dev Microbiol Mol Biol, 1(1), pp.75-94.

8. Ellaiah, P., Srinivasulu, B. and Adinarayana, K., 2002. A review on microbial alkaline proteases.

9. Ghildyal, N.P., Lonsane, B.K., Sreekantiah, K.R. and Sreenivasa Murthy, V., 1985. Economics of submerged and solid state fermentations for the production of amyloglucosidase. Journal of Food Science and Technology, 22(3), pp.171-176.

10. Gopalkumar G. Rao, Priyanka M. Patel, B.V. Rao and Rakeshkumar R. Pancha. 2016. Alkaline protease production by Aspergillus terreus BAB-346 using poultry litter waste. Int. J. Curr. Microbiol. App. Sci., 5(10):174-184.

11. Gupta, R., Beg, Q. and Lorenz, P., 2002. Bacterial alkaline proteases: molecular approaches and industrial applications. Applied microbiology and biotechnology, 59(1), pp.15-32.

12. Hossain, M.T., Das, F., Marzan, L.W., Rahman, M.S. and Anwar, M.N., 2006. Some properties of protease of the fungal strain Aspergillus flavus. International Journal of Agriculture and Biology (Pakistan). 
13. Hussain, Ahan, Mannam, Abdul,Zubair,Hursan et al.,(2010). Purification and characterization of Alkaline proteases from Aspergillus terreus.Journal of chemical society of Pakistan.32(4)497-504.

14. Ishikawa, H., Ishimi, K., Sugirura, M., Sowa, A.and Fujiwara, N.(1993).Kinetics and Mechanisms of enzymatic hydrolysis of gelatin of x-ray film and release of silver particles.J.Ferment.Bioeng.76:300-30

15. Joo, H.S., Kumar, C.G., Park, G.C., Kim, K.T., Paik, S.R. and Chang, C.S., 2002. Optimization of the production of an extracellular alkaline protease from Bacillus horikoshii. Process Biochemistry, 38(2), pp.155159.

16. Kaur, S., Vohra, R.M., Kapoor, M., Beg, Q.K. and Hoondal, G.S., 2001. Enhanced production and characterization of a highly thermostable alkaline protease from Bacillus sp. P-2. World Journal of Microbiology and Biotechnology, 17(2), pp.125-129.

17. Kirk, O., Borchert, T.V. and Fuglsang, C.C. (2002). Industrial enzymes applications. Curr. Opin. Biotechnol. 43: 473-481.

18. Kranthi, V.S., Rao, D.M. and Jaganmohan, P., 2012. Production of protease by Aspergillus flavus through solid state fermentation using different oil seed cakes. International Journal of Microbiological Research, 3(1), pp.12-15.

19. Oskouie, S.F.G., Tabandeh, F., Yakhchali, B. and Eftekhar, F., 2008. Response surface optimization of medium composition for alkaline protease production by Bacillus clausii. Biochemical Engineering Journal, 39(1), pp.37-42.

20. Osman, M.E., Khattab, O.H. and Elsaba, Y.M. 2014. Aspergillus terreus Proteases: Characterization and Applications. J. Chem. Bio. Phy. Sci. Sec. B,4 (3) : 2333-2346

21. Mukhtar, H., Ali, Z. and Riaz, N., 2004. Protease biosynthesis by mutant strain of Penicillium griseoroseum and cheese formation. Pakistan Journal of Biological Sciences (Pakistan).

22. Muthulakshmi, C., Gomathi, D., Kumar, D.G., Ravikumar, G., Kalaiselvi, M. and Uma, C., 2011. Production, purification and characterization of protease by Aspergillus flavus under solid state fermentation. Jordan J. Biol. Sci, 4(3), pp.137-148.

23. Naidu, K.S.B. and Devi, K.L., 2005. Optimization of thermostable alkaline protease production from species of Bacillus using rice bran. African Journal of Biotechnology, 4(7), pp.724-726.

24. Niyonzima, F.N. and More, S.S., 2015. Purification and characterization of detergent-compatible protease from Aspergillus terreus gr. 3 Biotech, 5(1), pp.61-70.

25. Pagare, R.S., Ramdasi, A.M., Khandelwal, S.R., Lokhande, M.O. and Aglave, B.A., 2009. Production and enzyme activity of an extracellular protease from Aspergillus niger and Bacillus subtilis. International Journal of Biotechnology \& Biochemistry, 5(3), pp.3-8.

26. Paranthaman, R., Alagusundaram, K. and Indhumathi, J., 2009. Production of protease from rice mill wastes by Aspergillus niger in solid state fermentation. World Journal of Agricultural Sciences, 5(3), pp.308-312.

27. Racheal, O.O., Ahmed, A.T.F., Ndigwe, E.V. and Morakinyo, S.D., 2015. Extraction, purification and characterization of protease from Aspergillus Niger isolated from yam peels. International Journal of Nutrition and Food Sciences, 4, pp.125-131.

28. Ramchandra, S., Singh, S., Larroche, C., Soccol, C., Pandey, A. 2007. Oil cakes and their Biotechnological applications - A review, Biores. Technol., 98: 2000-2009

29. Sabu, A., Sarita, S., Pandey, A., Bogar, B., Szakacs, G. and Soccol, C.R., 2002. Solid-state fermentation for production of phytase by Rhizopus oligosporus. Applied Biochemistry and Biotechnology, 102(1), pp.251-260.

30. Sharma, J., Singh, A., Kumar, R. and Mittal, A., 2006. Partial purification of an alkaline protease from a new strain of Aspergillus oryzae AWT 20 and its enhanced stabilization in entrapped Ca-Alginate beads. Internet $J$ Microbiol, 2(2), pp.1-14.

31. Srilakshmi, J. Madhavi, J and Ammani. K. 2014. Protease production by Humicola grisea through SSF.Global Journal of Bio-Science and Biotechnology. 3(3): 230-235.

32. Sumantha, A., Sandhya, C., Szakacs, G., Soccol, C.R. and Pandey, A., 2005. Production and partial purification of a neutral metalloprotease by fungal mixed substrate fermentation. Food Technology and Biotechnology, 43(4), pp.313-319.

33. Tremacoldi C.R., R. Monti. H. S. Selistre-De-Arau'jo . E. C. Carmona. 2006. Purification and properties of an alkaline protease of Aspergillus clavatus. World J Microbiol Biotechnol. 23:295-299.

34. Takami, H., Akiba, T. and Horikoshi, K., 1990. Characterization of an alkaline protease from Bacillus sp. no. AH-101. Applied microbiology and biotechnology, 33(5), pp.519-523. 